This report was prepared as an account of work eponsored by the United States Government. Nelther the onited States nor the United States Department of Energy, nor any of the1r employees, nor any of their contractors, subcontractors, or their employees, makes any warranty, expregs or iaplied, or assumes any legal liability or rasponsibility for the accuracy, completeness or ugefulness of any information, apparatug, product or proce日s digelosed, or reprasents that $1 \mathrm{ts}$ use wold not infringe privately orned rightg.

Printed in the United States of America

Avatlable from:

National Technical Information Serpice

D.S. Departuent of Comerce

5285 Port Royal Road

Springfiold, Virginia 22761

Price Printed Copy $s$; Microfiche $\$ 4.50$

* Pager

$1-25$

25-50

$51-75$

76-100

$101-125$

126-150

$151-175$

$176-200$

201-225

226-250

251-275

276-300

$301-325$

326-350

$351-375$

376-400

$401-425$

$426-450$

$451-475$

476-500

500-525

526-550

$551-575$

$567-600$

NTIS

Selling price

57. 00

$\$ 8.50$

510.00

$\$ 11.50$

$\$ 13.00$

$\$ 14.50$

$\$ 16.00$

$\$ 17.50$

$\$ 19.00$

$\$ 20$.

$\$ 22.00$

$\$ 23.50$

$\$ 25.00$

$\$ 26.50$

$\$ 28.00$

\$29. 50

$\$ 31.00$

$\$ 32,50$

$\$ 34.00$

515.50

$\$ 37.00$

$\$ 38.50$

$\$ 40.00$

$\$ 41,50$
For documents over 600 pages, add $\$ 1.50$ for each additional 25-page increment.

REPRODUCED FPM REST

AVALLAB!: ; 


\title{
HYDROGEN ISOTOPE TRAPPING ON GRAPHITE COLLECTOAS DURING AN ISOTOPE EXCHANGE EXPERIMENT IN THE TOKAMAK FUSION TEST REACTOR
}

\author{
PPPL--2599 S. J. Kilpatrick, M. Ulrickson, H. F. Dylla, D. M. Manos, and A. T. Ramsey \\ Princeton Plasma Physics Laboratory, Princeton, NJ 08543 \\ DE89 008657 \\ R. Nygren and Y. Hirooka \\ Institute of Plasma and Fusion Research, University of California at Los \\ Angeles, Los Angeles, CA 90024 \\ W. R. Wampler \\ Sandia National Laboratories, Albuquerque, NM 87185
}

\begin{abstract}
A rotatable collector probe was used to expose several graphite samples to a deuterium-to-hydrogen-to-deuterium exchange experiment in the Tokamak Fusion Test Reactor (TFTR) at the start of the 1988 operations period. This experiment proved the utility af helium conditioning discharges in accelerating the changeover process. Samples included portions of a tile taken from the inner bumper limiter (POCO AXF-5Q graphite) of TFTR during the recent machine opening, and coupons which had been conditioned in the Plasma Interactive Surface Component Experimental Station (PISCES) by exposure to a helium plasma. The samples were exposed to different groups of the $~ 1001.4 \mathrm{MA}$ discharges that comprised the experiment. They were removed and analyzed for retained deuterium and impurities by nuclear reaction analysis and Rutherford backscattering spectrometry. Codeposited carbon layers had been formed with thicknesses up to several tenths of a micron. The inferred percentages of trapped hydrogenic species were in general agreemeint with spectroscopic data. The computed carbon fluence per $D^{+}$discharge, $1.2 \times 10^{17} \mathrm{C} / \mathrm{cm}^{2}$, is compared to recent measurements on limiter tiles removed from TFTF.
\end{abstract}

(Presented at the 35th National Symposium of the American Vacuum Sociely, Atlanta, Georgia, 4-7 October 1988, and accepted for publication in the Journal of Vacuum Scierne and Technology.)

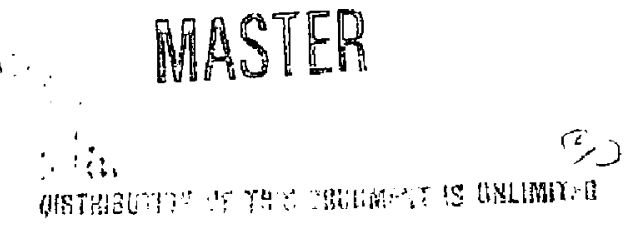




\section{Introduction}

In preparation for $D-T$ experiments on TFTR, there has been extensive study of first-wall conditioning techniques. ${ }^{1-5}$ In particular, a helium conditioning procedure was developed to control hydrogenic recyciing from the graphite axisymmetric bumper limiter and to produce an enhanced confinement ("supershot") mode $e^{6.7}$ with neutral beam heating. To study the eventual isotopic changeover in the limiter for D-T operation, species exchange experiments have been conducted. ${ }^{\beta}$ Long exchange times (from 60-600 discharges) have been observed using typical gas-fueled ohmic discharges. A recent exchange experiment' has been conducted using the helium conditioning technique to accelerate this process by first depleting the limiter surface of one hydrogen isotope before the second isotope is introduced.

The collector probe technique ${ }^{9-13}$ is a common method for studying particle fluxes in the plasma scrape-off layer (SOL). In this paper, we present the results of integrated flux measurements using a collector probe during the recent isotope exchange experiment. These results from the boundary layer are useful in understanding the changeover process and can be compared to other TFTR data, such as hydrogenic line emission intensities.

\section{Experimental}

2.1 The Isotope Exchange Experiment

The isotope exchange experiment began with a series of $\mathrm{He}^{+-}$ 
conditioning discharges to degas the limiter from previous $\mathrm{D}^{+}$operation. All of the discharges in this experiment were made at a plasma current. $\left.\right|_{p}$, of 1.4 MA with major radius $R=2.45 \mathrm{~m}$ and minor radius $\mathrm{a}=0.80 \mathrm{~m}$. Then a density scan was performed in hydrogen during which about 400 torr-liters of gas was puffed into the machine over eight discharges. Line integral electron densities were raised from $n_{\theta} l=1.9 \times 10^{15}$ to $4.0 \times 10^{15} \mathrm{~cm}^{-2}$ (diagnostic path length equals $160 \mathrm{~cm})$ over the course of the scan. The isotopic ratio $\mathrm{D} /(\mathrm{H}+$ D) near the bumper limiter changed from 0.76 to 0.45 as measured spectroscopically from $D_{\beta}$ and $H_{\beta}$ line emission. ${ }^{14}$ (It should be noted that this ratio does not exceed $\sim 0.8-0.9$ in TFTR due to residual hydrogen in the bulk of the graphite tiles. ${ }^{15}$ ) Subsequent $\mathrm{H}^{+}$"prefill-only" discharges (gas input only for plasma formation) showed that the limiter returned quickly to a

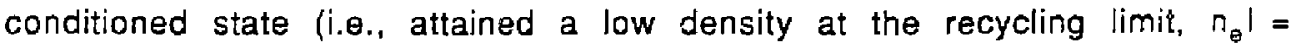
$\left.1.9 \times 10^{15} \mathrm{~cm}^{-2}\right)$.

The hydrogen was then depieted from the limiter surface with a short series (<10 discharges) of $\mathrm{He}^{++}$conditioning plasmas. This increased the isotopic ratio $\mathrm{D} /(\mathrm{H}+\mathrm{D})$ to 0.62 . The changeover back to deuterium was accomplished in a $D^{+}$density scan over the same range of electron densities as the $\mathrm{H}^{+}$scan. After six discharges and about 340 torr-liters of gas, the isotopic ratio had returned to 0.79 .

\subsection{Exposures}

The TFTR CESEP (Çombined Electrical and Sample Exposure Probe) diagnostic, described in detail elsewhere ${ }^{16}$ consists of a translatable probe cylinder which rotates behind tantalum slits in an outer housing. The slits 
face into the ion and electron drift directions, and were set at their maximum separation of $1 \mathrm{~cm}$. The probe enters the vacuum vessel from below. Graphite was chosen as the sample material for its thermal properties, and so that the surface chemistry during exposure would be of the $C: H$ system as on the limiter surface. Three different types of graphite were chosen as samples. The first type, composed of POCO AXF-5Q graphite, included portions of a tile from a high flux area of the TFTR bumper limiter which was removed during the 1987 opening. Surface analysis of several tiles removed in that opening ${ }^{17}$ showed that high flux areas were relatively clean (low amounts of deuterium and impurities) and presumably underwent net erosion. These samples were outgassed under vacuum at $600^{\circ} \mathrm{C}$ to desorb trapped $\mathrm{D}$ and $\mathrm{H}$ prior to mounting on the probe. The second type included coupons of POCO HPD-1 graphite which had been conditioned in the Plasma Interactive Surface Component Experimental Station (PISCES) by exposure to a helium plasma. High-fluence helium plasma bombardment (up to $10^{21}$ ions $/ \mathrm{cm}^{2}$ ) in PISCES removes graphite dust particles blocking the intrinsic pores of POCO graphite and generates a sponge-like porous surface morphology. ${ }^{18}$ These two sample types were chosen to study the effect of pore strlicture on particle collection. This subject will not be addressed further in this paper. The third type included fresh samples of ATJ graphite, which were sanded, ultrasonically cleaned in alcohol, and baked to $500^{\circ} \mathrm{C}$.

These samples were mounted lengthwise on the inner prube cylinder, and also on the probe shell in place of one tantalum slit on the electron drift side, as illustrated in Figure 1. By rotating the inner cylinder, different portions of the samples were exposed to plasmas from the different phases of the changeover experiment (with the exception of the initial $\mathrm{He}^{++}$conditioning 
phase, which was not studied). The exposures were overlapped slightly to create regions where the effect of two consecutive phases could be observed. The grouping of samples attached to the outer housing integrated the exposure from the discharges for which the probe was deployad. This experiment concentrated on particle collection in the electron drift direction based on the results of earlier probe measurements. ${ }^{13}$ It was observed that sma!ler fluxes were collected on the ion drift side, which was attributed to shorter connection lengths (the distance along a field line to the first solid cbject). For these plasmas the connection lengths on the electron drift side were $-21-25 \mathrm{~m}$, compared to $\sim 2-3 \mathrm{~m}$ on the ion drift side.

After the initial $\mathrm{He}^{++}$degassing of the limiters, the probe was inserted to within a distance $d=10 \mathrm{~cm}$ of the plasma boundary. An exposure was made to fifteen $\mathrm{H}^{+}$discharges which began with the density scan described above. The average density was $n_{\theta} l=3.0 \times 10^{15} \mathrm{~cm}^{-2}$. The second exposure was to seven $\mathrm{He}^{++}$conditioning plasmas with an average density of $\mathrm{n}_{\theta} \mathrm{l}=$ $2.3 \times 10^{15} \mathrm{~cm}^{-2}$. The probe was reinserted later to $d=14 \mathrm{~cm}$ for a series of twelve $\mathrm{D}^{+}$plasmas just after the deuterium density scan referred to above was completed. Problems with the density feedback system led to two high density disfuptions during the exposure. The average density was $n_{\theta} l=$ $3.3 \times 10^{15} \mathrm{~cm}^{-2}$.

\subsection{Analysis}

After these exposures the samples were removed in air to argon-filled bags and examined later by two analytical techniques. The areal density of retained deuterium was measured using ${ }^{3} \mathrm{He}(d, p){ }^{4} \mathrm{He}$ nuclear reaction ana!ysis 
(NRA) with a $700 \mathrm{keV} 3 \mathrm{He}$ analyzing beam. The data coliection was automated to make a measurement every $0.5-1.0 \mathrm{~mm}$ along the sample axis using a dose of 0.1-0.4 $\mu \mathrm{C}$ and an analysis beam spot size of $1.0 \times 2.0 \mathrm{~mm}$. Lateral scans across the different exposure stripes were made with a measurement spacing of $0.2 \mathrm{~mm}$ and a spot size of $0.3 \times 2.0 \mathrm{~mm}$. Rutherford backscattering spzctrometry (RBS) using a $2 \mathrm{MeV}{ }^{4} \mathrm{He}$ bearr. was used to determine the amount of codeposited carbon, oxygen, and metallic impurites on the samples.

\section{Results}

\subsection{Retained Deuterium}

Figure 2 shows the retained detiterium per exposure measured by NRA for different phases of the isotope exchange experiment as a function of distance to the plasma midplane, both for the ion and electron drift directions. Because the probe axis does not pass through the plasma center, the abscissa is not quite a measure of radial position, and the plasma boundary would be intersected at $77.5 \mathrm{~cm}$, not $80.0 \mathrm{~cm}$. The gaps in the electron side data correspond to the spacing of the samples of PISCES, TFTR, and fresh graphite on the probe cylinder, with the PISCES samples closest to the plasma or toward the right side of the figure. The scrape-off lengths, $\lambda$, associated with these radial profiles, assuming exponential decay (and correcting to a radial measurement), are also shown. They were fairly long on the electron side, varying from $7.8 \mathrm{~cm}$ for $\mathrm{H}^{+}$plasmas to $\sim 11 \mathrm{~cm}$ for $\mathrm{D}^{+}$ plasmas. The samples attached to the outer cylinder which integrated all the exposures recorded a scrape-off length of $12.2 \mathrm{~cm}$. Long decay lengths were ooserved earlier ${ }^{13}$ for collecting samples in the middle of the SOL. The 
scrape-off lengths on the electron side were calculated without the data from the TFTR graphite samples (the outlined symbols). It was assumed that these data fell consistently above the calculated curves due to some remaining deuterium in those samples after outgassing. The residual amount may be estimated as the average vertical distance from the data to these curves, approximately $5-7 \times 10^{16} \mathrm{D} / \mathrm{cm}^{2}$.

As wili be discussed later, the deuterium along with hydrogen is dispersed in a layer of redeposited carbon to its saturation limit. which is perhaps similar ${ }^{17}$ to the limit in bulk graphite of $\sim 0.44$ hydrogenic atoms per carbon. ${ }^{19}$ Thus, these radial profiles and scrape-off lengths refer not to the incident deuterium, but to the in wejent carbon flux whicil determines how much deuterium is codeposited with the carbon.

The electron side to ion side retained deuterium ratios were large, $\sim 15$ closer to the plasma increasing to $\sim 30$ further back for the $\mathrm{H}^{+}$exposure, and varying from $\sim 15$ to $\sim 45$ in the same way on the stripe which saw the $\mathrm{H}^{+}$plus the $\mathrm{He}^{++}$plasmas. This is similar to earlier probe measurements, ${ }^{13}$ and could be due to much shorter connection lengths on the ion drift side.

Lateral scans across the centers of the PISCES samples and the TFTR samples on the inner cylinder are shown in Figure 3 . In general the $\mathrm{H}^{+}, \mathrm{He}^{++}$, and $\mathrm{D}^{+}$exposures deposited faily equal amounts of deuterium, on the order of $3-4 \times 10^{17} \mathrm{D} / \mathrm{cm}^{2}$. The overlaid regions $\left(\mathrm{H}^{+}\right.$plus $\mathrm{He}^{++}$and $\mathrm{He}^{++}$plus $\left.\mathrm{D}^{+}\right)$had approximately double this amount. A shadowed region contained measurable amounts of deuterium, indicating that multiple scattering of these low energy ions ${ }^{20}$ probably occurred. By taking the difference between the measurements 
on the TFTR and PISCES samples in the shadowed region, another estimate if the residual deuterium in the TFTR samples is $-8.5 \times 10^{16} \mathrm{D} / \mathrm{cm}^{2}$.

\subsection{Impurities}

The areal densities of carbon, oxygen, and metals deposited on the electron side samples were measured at selected locations using RBS. The deposited material consisted mainly of carbon with smaller amounts of oxygen, chromium, iron, and nickel. Areal densities of the oxygen and motals were determined from the backscattering yield. The areal density of deposited carbon was estimated in two ways. Helium scattering from oxygen deep in the carbon arrives at the detector with less energy than helium scattered from oxygen at the surface due to the energy lost passing through the layer. Thus the thickness of the oxygen-containing layer can be determined from the energy spread of the oxygen backscattering peak. This method could not be used for layers thicker than about $0.45 \mu \mathrm{m}$ due to overlap of the oxygen peak with the backscattering from the carbon. The second method for estimating the areal density of deposited carbon utilized the shape of the carbon edge in the uackscattering spectrum. A near-suriace layer consisting partly of carbon gives a lower backscattering yield than a pure carbon target. Therefore the thickness of the impure dencsited layer could be determined by comparing the RBS spectrum for a pure carbon reference target to the RBS spectrum of the sample. As before, it is the different energies of the particles scattering from atoms at the front and rear of the deposited layer which is used to determine the layer thickness. The thicknesses reported here were obtained from the atomic areal densities measured by RES using a value of $1.8 \mathrm{~g} / \mathrm{cm}^{3}$ for the density of the deposited 
material. Sidface roughness introduces a significant uncertainty in the measurements on the order of $\pm 20 \mathrm{~nm}$, estimated from the width of the oxygen peak on samples which had very iitile deposited material.

The P!SCES samples, which were the closest to the piasma had the thirfest carbon overlayars. The samples un the electron side were brightly colored from vhite light interference in ihese films. From their colors we can infer ${ }^{21}$ that the film thicknesses increaseci slowly in the direction of the plasma boundary, in concert with the cleuterium NRA signals. On the ion side the films were of insufficient thickness to see this effect $(<30 \mathrm{~nm})$. Table 1 summarizes the RBS measurements by giving the overlayer thicknesses and their relative deuteriuin, oxygen, and metals content.

\section{Discunsion and Conclusion:}

The success of the helium conditioning technique in accelerating the isotope changeover process can be obseived in these data. As is seen in Table I, the $D / C$ ratio measured in these layers varies from 0.11 for the $\mathrm{H}^{+}$exposure to $\sim 0.24$ for the $\mathrm{He}^{++}$exposure to 0.36 for the $\mathrm{D}^{+}$exposure. However, the story of the retained hydrogen in these layers must also be considerad. Previous measurements in TFTR ${ }^{13}$ and JET22 showed that saturated carbon layers tend to form on collecting samples in the SOL of plasmas containing a lot of carbon. Therefore, it is assumen here that the carbon layers in all cases are filled to saturation by hydrogenic species, i.e., $(D+H) / C=0.44$. Then the isotopic ratios for these exposures become $\mathrm{D} /(\mathrm{H}+\mathrm{D})=0.25$ for the $\mathrm{H}^{+}$ exposure, 0.55 for the $\mathrm{He}^{++}$exposure, and 0.82 for the $\mathrm{D}^{+}$exposure. This agrees reasonably well with the spectroscopic data. The ratio $D_{\beta} /\left(H_{\beta}+D_{\beta}\right)$ 
from the spectroscopy drops from 0.76 to 0.45 after the first few $\mathrm{H}^{+}$ discharges, whereas the collector probe measurement, which integrated over all the $\mathrm{H}^{+}$plasmas, gives $\mathrm{D} /(\mathrm{H}+\mathrm{D})=0.25$. The spectroscopic ratio at the beginning of the $D^{+}$phase is 0.62 , compared to the ratio of $D /(H+D)=0.55$ from the collector probe exposed to the $\mathrm{He}^{++}$discharges, which directly preceded the $\mathrm{D}^{+}$operation. Finally, the spectroscopic ratio had climbed back to 0.79 after the first few $\mathrm{D}^{+}$discharges, whereas the collector probe measurement which integrated over a series of $\mathrm{D}^{+}$plasmas after the initial $\mathrm{H}$-to-D changeover had taken place showed a ratio of 0.82 .

The discrepancies between the probe and spectroscopic nieasurements could be explained by where the measurements are made. The $H_{\beta}$ measurements are made along a sightline from the outer equator to a spot just below the bumper limiter center, while the probe makes local measurements at the bottom of the machine. Any poloidal asymmetries would lead to differing results. Also, the spectroscopy data are doeninated by emission generally near the plasma boundary, while the probe is deployed in roughily the middle of the SOL. Edge phenomena with short scale lengths (less than a couple $\mathrm{cm}$ ) would not contribute to the probe data.

Other features of the isotope exchange experiment can be drawn from these collector probe results. As expected,' the $\mathrm{He}^{++}$plasmas, which had the lowest electron densities, deposited the largest quantities of carbon and metals per discharge, $3.2 \times 10^{17} \mathrm{C} / \mathrm{cm}^{2}$ and $1.6 \times 10^{15} \mathrm{metals} / \mathrm{cm}^{2}$ on the PISCES sampie. The most oxygen was seen in the $\mathrm{H}^{+}$exposure, with $>2.1 \times 10^{16} \mathrm{O} / \mathrm{cm}^{2}$ per discharge. The least carbon, oxygen, arid metals were found in the $D^{+}$ exposure, for which the electron densities were the highest: $1.2 \times 10^{17} \mathrm{C} / \mathrm{cm}^{2}$, 
$1.2 \times 10^{16} \mathrm{O} / \mathrm{cm}^{2}$, and $8.9 \times 10^{14} \mathrm{metals} / \mathrm{cm}^{2}$ per discharge.

It is interesting to compara these results with recent external analyses of limiter tiles removed from TFTR. ${ }^{16}$ We assume parallel flow (along the same flux surface) to low flux areas on the limiter surface with unity sticking coefficients on the samples and limiter tiles, and ignore erosion effects on the deposited layers. Low flux areas of the limiter were characterized by thick $\left(\sim 10 \mu \mathrm{m}\right.$ if $\left.\rho=1.8 \mathrm{~g} / \mathrm{cm}^{3}\right)$ carbon deposits with 20 at\% $D$, 6 at\% $O$, and 1 at\% metals after 9922 discharges. The probe data are multiplied by the sine of the angle a field line makes as it strikes the limiter surface to account for oblique deposition. For the deuterium discharges, we calculate that the fluences to the limiter are $2.3 \times 10^{16} \mathrm{C} / \mathrm{cm}^{2}, 2.6 \times 10^{15} \mathrm{O} / \mathrm{cm}^{2}$, $1.9 \times 10^{14} \mathrm{metals} / \mathrm{cm}^{2}$, and a lower bound of $9.0 \times 10^{15} \mathrm{D} / \mathrm{cm}^{2}$ per discharge. These values overestimate the amounts of material found on the limiter by factors of $2-5$.

In summary, these collector probe measurements are in general agreement with spectroscopic data on the isotopic ratio $D /(H+D)$ during an isotope exchange experiment with helium conditioning. Thick codeposited carbon layers were formed on different types of graphite samples with no observable dependence on the type of sample. These data overestimate somewhat the amount of material which accumulates on low flux areas of the bumper limiter, as compared to measurements on removed bumper limiter tiles.

\section{Acknowledgments}


This work was supported by U. S. Department of Energy Contract Nos. DE-AC02-76-CHO-3073 and DE-AC04-76DP00789. Our thanks to R. Bastasz for helpful discussions regaroing the data. 


\section{References}

1 H. F. Dylla, M. Ulickson, M. G. Bell, D. K. Owens, D. Buchenauer et al., Proc. 8th Intern. Conf, on Plasma Surface Interactions, Julich, 1988 (accepted for publ. in J. Nucl. Mater. 162-164).

2 H. F. Dylla, P. H. LaMarche, M. Ulrickson, R. J. Goldston, D. B. Heifetz et al., Nusl. Fusion 27. 1221 (1987).

3 H. F. Dylla and the TFTR Team, J. Nucl. Mater. 145/147, 48 (1987).

4 M. Ulrickson, H. F. Dylla, P. H. LaMarche, and D. Buchenauer, J. Vac. Sci. Technol. A6, 2001 (1988).

5 W. R. Wampler and B. L. Doyle, Proc. 8th Intern. Cont. on Plasma Surface Interactions, Julich, 1988 (accepted for publ. in J. Nucl. Mater. 162-164).

6 J. D. Strachan, M. Bitter, A. T. Ramsey, M. C. Zarnstorff, V. Arunasalam et al., Phys. Rev. Lett. 531004 (1987).

7 R. J. Goldston, V. Arunasalam, M. G. Bell, M. Bitter, W. R. Blanchard et al., in Proc. 11th Intern. Conf. on Plasma Physics and Controlled Nuclear Fusion Research, Kyoto, 1986 (IAEA, Vienna, 1987) Paper No. IAEA-CN-47/A-II-1.

B P. H. LaMarche, H. F. Dylla, P. J. McCarthy, and M. Uirickson, J. Vac. Sci. Technol. A4, 1198 (1986).

${ }^{9}$ G. Staudenmaier, J. Vac. Sci. Technol. A3, 1091 (1985).

${ }^{10}$ R. Behrisch, J. P. Coad, J. Ehrenberg, G. F. Neill, J. Partridge et al., Proc. 8th Intern. Conf. on Plasma Surface Interactions, Julich, 1988 (accepted for publ. in J. Nucl. Mater. 162-164).

$11 \mathrm{H}$. Grote and the WASA Team, Proc. 8th Intern. Conf. on Plasma Surface Interactions, Julich, 1988 (accepted for publ. in J. Nucl. 
Mater. 162.164).

12P. Weinhold, J. Winter, H. G. Esser, F. Waelbroeck, H. Bergsałker et al.,

J. Nucl. Mater. 145/147, 642 (1987).

13S. J. Kilpatrick, H. F. Dylla, W. R. Wampler, D. M. Manos, S. A. Cohen et al., Proc. 8th Intern. Conf. on Plasma Surface Interactions, Julich, 1988 (accepted for publ. in J. Nucl. Mater. 162-164).

${ }^{14}$ A. T. Ramsey and S. L. Tumer, Rev. Sci. Instrum. 228, 1211 (1987).

15R. Bastasz, J. Vac. Sci. Technol. A6, 2116 (1988).

16 R. Mastronardi, R. Cabral, and D. Manos, in Proc 10th Symo. on Fusizn Engineering, Fhiladelphia, 1983 (IEE 三, New York, 1983) p. 1507.

${ }^{17} \mathrm{H}$. F. Dylla and K. !. Wilson, eds. Tritium Retention in TFTR, Joirt Report, Princeton Plasma Physics Laboratory Report No. PPPL-2523 and Sandia National Laboratories No. SAND-88-8212, April 1988.

18 Y. Hirooka, W. K. Leung, R. W. Conn, D. M. Goebel, B. Labombard et al., J. Vac. Sci. Technol. A6, 2965 (1988).

19W. R. Wampler, D. K. Brice, and C. W. Magee, J. Nucl. Mater. 102, 304 (1981).

20S. A. Cohen, H. F. Dylla, W. R. Wampler, and C. W. Magee, J. Nucl. Mater. 93/94, 109 (1980).

21P. Weinhold, F. Waelbroeck, J. Winter, and H. G. Esser, Proc. 8th Intern. Conf. on Plasma Surface Interactions, Julich, 1988 (accepted for publ. in J. Nucl. Mater. 162-164).

$22 \mathrm{H}$. Bergsaker, J. P. Coad, L. de Kock, B. Emmoth, J. Hancock et $\varepsilon^{\prime}$., in Proce 14th Europ Conf on Controlled Fusion and Plasma Physics, Madrid (1987) Part II, p.732. 


\section{Figure Captions}

Figure 1 Schematic of sample positions on collector probe.

Figure 2 Deuterium areal densities per exposure versus distance to the plasma midplane for different segments of the isotope exchange experiment. The straight lines are the linear regression fits to the data. The scrape-off lengths are also given. The solid symbols are for the PISCES samples, the outlined symbols are for the TFTR sarnples, and the upen symbols are for the fresh samples.

Figure 3 Retained deuterium lateral scans across the centers of the PISCES and TFTR samples on the inner probe cylinder, showing the effect of the different phases of the changeover experiment. 


\section{TABLE I \\ ANALYSIS SUMMARY}

LAYER

metals

EXPOSURE THICKNESS (um) O/C /C D/C

PISCES SAMPLES

$\begin{array}{crrrr}\mathrm{H}^{+} & >0.45 & 0.09 & 0.005 & <0.11 \\ \mathrm{H}^{+} / \mathrm{He}^{++} & >0.45 & 0.09 & 0.006 & <0.19 \\ \mathrm{He} & 0.25 & 0.05 & 0.005 & 0.21 \\ \mathrm{He}^{++} / \mathrm{D}^{+} & 0.27 & 0.12 & 0.008 & 0.24 \\ \mathrm{D}^{+} & 0.11 & 0.11 & 0.008 & 0.35\end{array}$

TFTR SAMPLES

$\begin{array}{ccccc}\mathrm{H}^{+} & 0.38 & 0.08 & 0.004 & 0.11 \\ \mathrm{H}^{+} / \mathrm{He}^{++} & 0.38 & 0.07 & 0.004 & 0.20 \\ \mathrm{He} & 0.17 & 0.05 & 0.003 & 0.26 \\ \mathrm{D}^{++} & 0.10 & 0.15 & 0.006 & 0.37\end{array}$


$\$ 88 \times 1168$
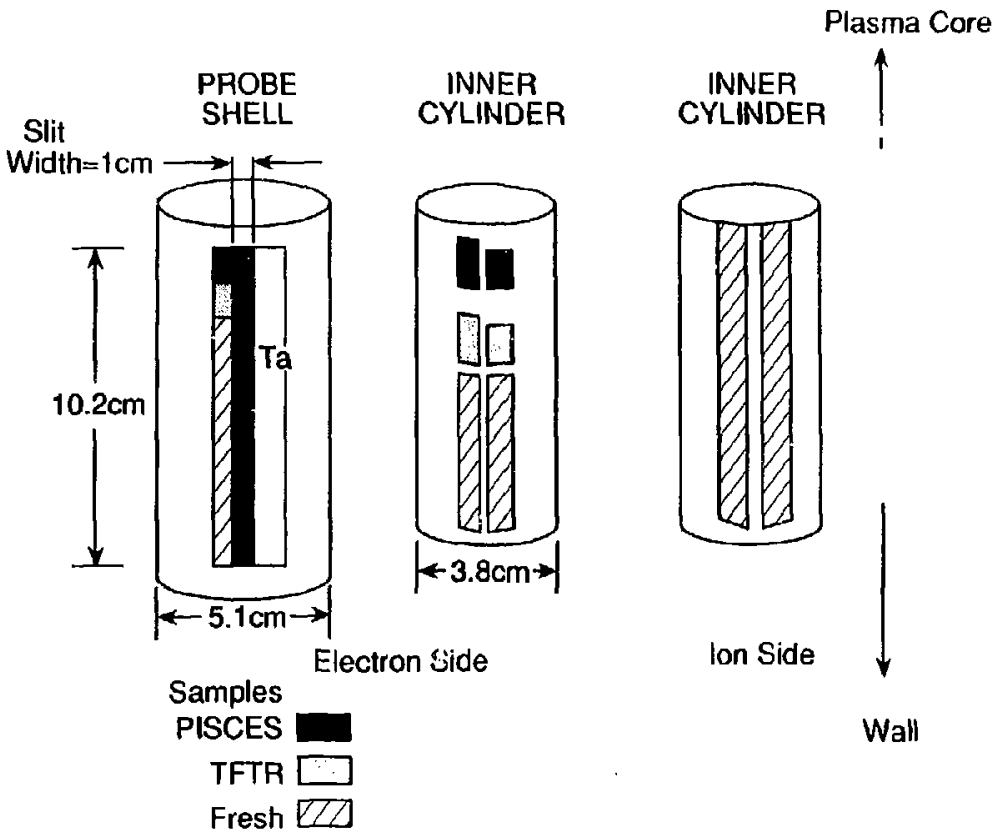

Ion Side

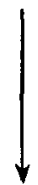

Wall 


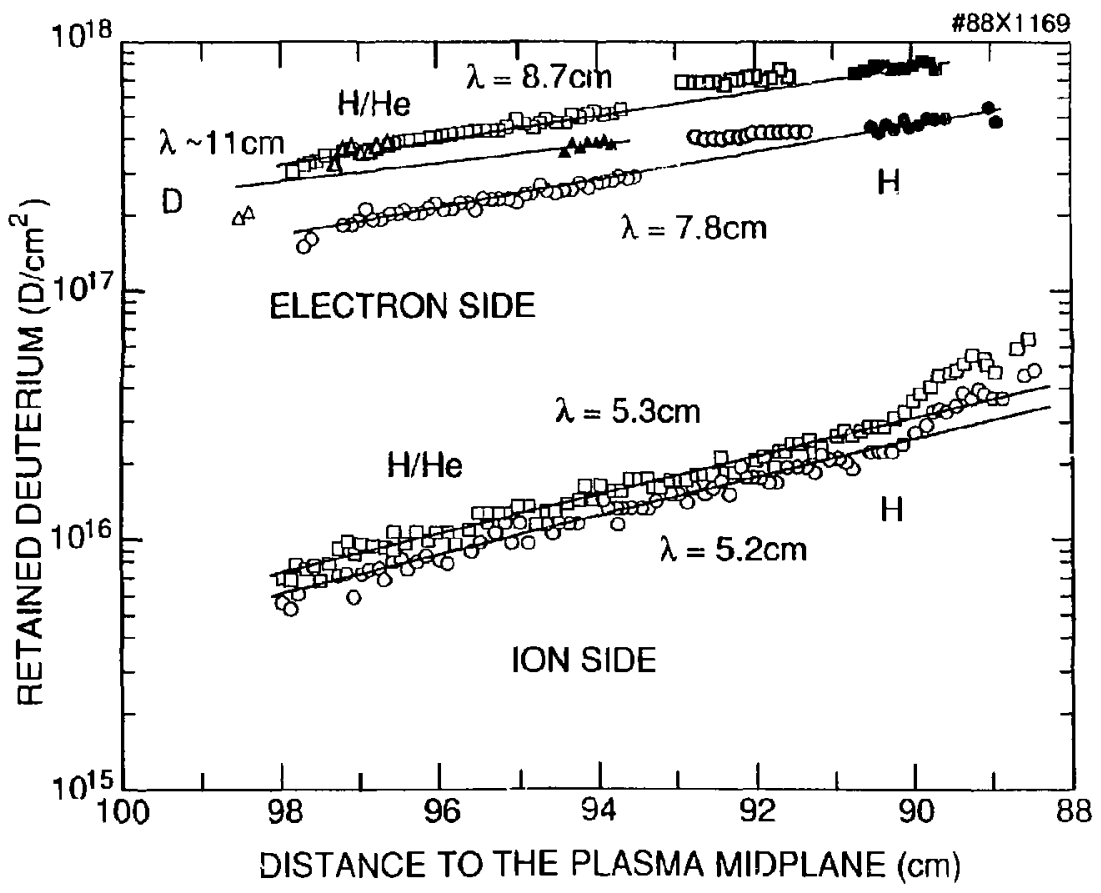




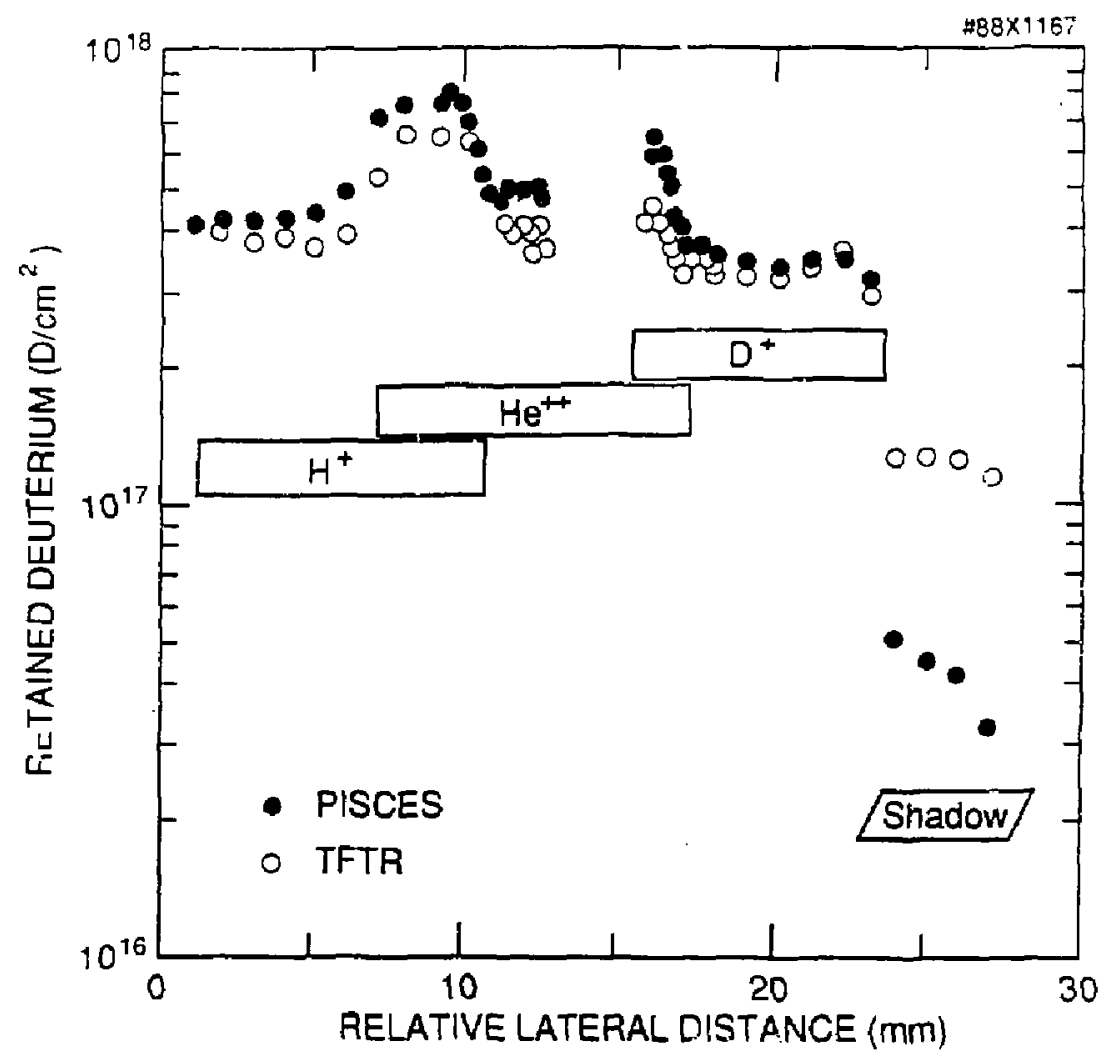

F's. 3 
Dr. Fronk J. Pootoni, Univ of wolionggond, AUSTRalia

Prot. M.M. Brennan, In iv Syaner, australia

Prasena Researeh Lab., Australian Mat. Univ.. AUSTRALIA

Prof, i.R. Jones, Flinders Univ., AUSTRALIA

Prof. F. Cod, Inst Theo Phys, AUSTRIA

Prot. M. Mander.instut tur Thearotische Physik, AUstRIA

M. Gaossens, Astronomiseh Instituut, BELGILA

Ecole Royala militairo, Lad do Phys PIasmas, gelgium

Comsission-European, Dg-Xll 1 Fusion Prag, BELGJiD

Prot. R. Boucique, Laborateriun voor Nafuurkunde, BELGIJH

Dr. P.H. Sakonaka, Instituto Fisica, BRAzIL

Instituto De Pegquigos Espaciasi-INPE, GRAZIL

Documants office, Atomic Energy of Conada Limited, CaknOA

Or. M.P. Bachynski, Me Technologies, Inc., CAMAOA

Or. H.M. Sharsgard, Univorsity at 5askareneman, CANADA

Dr. H. Barnard, Jaivergity of Rritish Columoia, CANadh

Prof. J. Toiehmann, Univ. of Hontraal, CANADA

Prof. S.R. Sreenivason, Univorgity of Caigary, Cyuan

Prot. Tuear W. Lannston, INRS-Enargie, CANADA

Dr. Boiten, Contre eanedion de fusion magnélique, CaNhOA

Or. C.A. James, Univ. of Alberta, CAMADA

Or. Pefer Lukac, Kosenskeno Univ, CZECHOSLOVAKIA

Tha bibrarien, Culham Laboratory, ENGLAND

The Librarisn, Rutherfora ADDiaron LBDOratory. ENGLAHO

Mrs. S.A. Huteninson, IET Library, ENGLANo

C. Woutror, bab. de Physique das milieux lonisás. France

J. Radat, CEN/CAOARACHE - BAt SOS. FRANCE

Ms. C. Binni, Librarian, Univ. of lognnina, EAEECE

Or. Tom mul. Academy Bialiograchic Ser., hong kong

Preprint Library. Hungarian Acadeay of Sciences, HuMgary

Or. B. Des Gudta, Stho inst of Hucl. Phys., IRDiA

Or, P, Kar, Instituto for Plasma Researeh, INDiA

Or. Pnilid Rosenal, istael inst. at Tech, ISRAEL

Librarian, Int'l Cte Theo Phys, italy

Frof. G. Rostagni, Istituto Gas Ionizzati dal CH, I TALY

Misg clolia Do Pslo, Assoe EURATOM-ENEA, ITALT

Or. G. Grosso, istituto di figica del Plasma, i taly

Dr, H. YangTo, Tosnitie Res \& Cov, JAPAN
Prot. 1. Kamokemi, Atonic Enargy Res. Institure, aPaN

Prof. Kyoji Nishikawa, Univ of Miroshima, JAPAN

Director, Dadt. Large Tokamak Res. JAER', JAPAN

Prof. Satoshi Itoh, Kyughu University, JaPAN

Researen info Canter. Nagoyo University, AAPAN

Prof. S. Tankka, Kyoto University, JAPAN

Library, Kyoto Iniversity, JAPAN

Prof. Moduyuki Inoue, University of TOKYO, APAN

5. Hor i, JAERI, JAPAN

H. Jeong, Librarian, Koroa Advonced Energy Res inst, KOREA

Prof. D.I. Chai, The Korad Adv, Inst of Se $i$ s Toen, KOREA

Prof. B.s. Liley, University of Woikato, NEW ZEALAND

Ingtitute of PIasea Physics, FEOPLE's REPUBLIC OF CHINA

Librarian, lisstitute of Phys., PEOPLE'S REPU⿴lic OF CHINA

Library. Tsing Ho University, PEOPLE'S REPUBLiC OF CHINA

z. Li, Southmast inst. Physics. PEOPLE'S REPUBL. C OF CHiva Prof. J.A.C. Cabral, Inst Suberior Tecnice, PORTLGAL

Dr. Qetavian Patrus, AL I COZZA Univargigy, zOMANIA

Or. Jan de villiars, Fusion studies, AEC, 50 dFarCA

Prof. M.A. Halloarg, University of Matal, SU AFRICA

C. 1,E.M.A.T., Fusion Div. Library, SPAIN

Or. Lennart Stenfio, University Of JAEA, SWEDEN

Library, Royel Institute of Toch, SWEDEN

Prof, Hens withelmson. Chajmers univ of Tect, SAEDEN

centre Phys des Plasinas, Ecole Polytecri Fed, SwitzerLano

Bibl iotheak, Fon-lngt yoor Pl asme-Fysica, THE NETHERLANDS Motin Durgut, Middte East Tochnical University, TURKEY

Or, 0.0. Ryurov, Siberian Acod Scl, USSR

Or, G.A. Eliseav, Kurengtor institute, USSR

Dr. V.A. Glukhikh, Inst Eletrophysical Adparatus, USSR

Prof. O.S. Padichenko. Inst, of Phys. I Tech. Ussa

Or. L.M. Kovriznnykn, Instituto of Gan. Physics, U552

Nuclear Res. Establishent, Julieh LYA., iw. GEPGMANY

gioliothak, Inst. Fur Plasagaforschung, W. GEPMANY

Dr. K. Sehindlor, Ruhr-Universitat Bochuet, M. GEFonany

ASDEX Rading Ro, c/o kagnor, IPP/Max-Pl anCK, M. GERMANT

Librarian, Maxtionck Ingtitut, W. GERan"

Prof. R.K. Janev, inst of Phrs, Yugoslayia 